King's Fund, London, UK

v.raleigh@kingsfund.org.uk

Cite this as: BMJ 2022;376:0427

http://dx.doi.org/10.1136/bmj.0427

Published: 23 February 2022

\section{Ethnic differences in covid-19 death rates}

\author{
A complex and evolving picture that demands close monitoring \\ Veena S Raleigh senior fellow
}

Higher covid-19 mortality among ethnic minority groups in England and Wales has been a constant finding throughout the pandemic. ${ }^{1}$ Ethnic differences lessen substantially when factors that increase the risk of infection and adverse outcomes are taken into account-such as geography, deprivation, occupation, household composition, living arrangements, and pre-existing health conditions. The Office for National Statistics is now also examining the effect of vaccination status. Its latest analysis shows that ethnic differences in mortality have changed over time, ${ }^{2}$ reflecting the complex relation between ethnicity and risk of dying from the virus, and highlighting the need for ongoing monitoring.

\section{Excess deaths}

One of the most notable takeaway messages is that excess covid-19 mortality among most ethnic minority groups has fallen over time compared with the White British group. The groups at greatest risk have also changed over time: at the start of the pandemic, covid-19 mortality was highest in the Black African group, ${ }^{1}$ whereas in subsequent waves it was highest in Bangladeshi and Pakistani groups. ${ }^{2}$

In the most recent wave to December 2021, only Pakistani men and Bangladeshi men and women experienced excess mortality compared with the White British group after adjustment for sociodemographic and health factors and vaccination status. These groups are more likely to live in large households with multigenerational families, which could increase the risk of infection and contribute to their higher risk of death. ${ }^{3}$ Since its introduction in December 2020, the vaccination programme has helped to reduce excess deaths from covid-19 in most ethnic minority groups, especially people identifying as Black Caribbean and Black African.

These findings have important implications for health and public health services in the UK and beyond. Risk of death from covid-19 is more than 90\% lower for people who have had a third vaccination dose than for unvaccinated people. ${ }^{4}$ Although it is encouraging that excess mortality has narrowed over time for most ethnic minority groups, facilitated in part by the vaccination programme, vaccine uptake remains lowest in ethnic groups with the highest risk of covid-19 death in all three waves-only 34\% of Black Caribbean, 38\% of Black African, 38\% of Pakistani, and $46 \%$ of Bangladeshi adults have had three vaccine doses compared with $68 \%$ of White British adults. ${ }^{5}$

Low vaccination rates among pregnant women generally, and especially among those from ethnic minority groups, have been a particular concern, given the evidence of both vaccine safety and the risk of adverse outcomes without vaccination. ${ }^{6}$ About half of pregnant women in the UK who died from complications of covid-19 between June 2020 and March 2021 were from Asian and Black ethnic groups. ${ }^{7}$ Even before the pandemic, maternal death rates among these groups were respectively double and quadruple those in the White British group. ${ }^{8}$

If ethnic disparities in covid-19 mortality are to be reduced further, services must find new ways of engaging with local communities and organisations, provide information in culturally appropriate formats, and improve accessibility to increase vaccine uptake. Ethnic disparities in covid-19 mortality are seen not just in the UK but in other high income countries. ${ }^{9}$ Evidence that vaccination programmes can reduce these disparities therefore has relevance beyond the UK.

\section{Socioeconomic factors}

Geography and socioeconomic factors such as deprivation and occupation drive much of the excess covid-19 deaths seen in all ethnic groups. Their impact has been greatest among Bangladeshi, Pakistani, Black Caribbean, and Black African people, who are over-represented among the most deprived communities in England. ${ }^{10}$ But it is not limited to ethnic minority groups-covid-19 mortality in the most deprived areas of England is more than double that in the least deprived areas, ${ }^{11}$ and the pandemic has notably exacerbated pre-existing health inequalities associated with deprivation.

The ONS analysis also shows that all-cause mortality in most ethnic minority groups (with the exception of Bangladeshi and Pakistani groups, and Black Caribbean men) during the pandemic was similar to or lower than that in the White British group ${ }^{2}-$ which is consistent with their lower all-cause mortality before the pandemic. ${ }^{12}$ This should, however, not deflect from the need for preventive measures to reduce the much higher burden of morbidity and mortality from some chronic diseases, including cardiovascular disease and diabetes, among Asian and Black communities. This burden also exacerbated their vulnerability to adverse covid-19 outcomes. The Office for Health Improvement and Disparities should prioritise such measures to reduce ethnic disparities in health.

We need to tackle the socioeconomic inequalities driving the disproportionate impact of the pandemic, and health inequalities more generally, in both ethnic minority groups and deprived groups of all ethnicities. The "levelling up" white paper sets ambitious "missions," including for increasing healthy life expectancy and reducing geographical 
inequalities. However, levelling up will rapidly become a meaningless slogan without tangible reductions in the gross health disparities experienced by too many in the UK.

Competing interests: We have read and understood BMJ policy on declaration of interests and have no relevant interests to declare.

Provenance and peer review: Not commissioned, not externally peer reviewed.

1 Office for National Statistics. Updating ethnic contrasts in deaths involving the coronavirus (COVID-19), England: 24 January 2020 to 31 March 2021. 2021. https://www.ons.gov.uk/peoplepopulationandcommunity/birthsdeathsandmarriages/deaths/articles/updatingethniccontrastsindeathsinvolvingthecoronaviruscovid19englandandwales/24january2020to31march2021

2 Office for National Statistics. Updating ethnic contrasts in deaths involving the coronavirus (COVID-19), England: 8 December 2020 to 1 December 2021. 2022.

https://www.ons.gov.uk/peoplepopulationandcommunity/birthsdeathsandmarriages/deaths/articles/updatingethniccontrastsindeathsinvolvingthecoronaviruscovid19englandandwales/8december2020to1december2021

3 Nafilyan V, Islam N, Ayoubkhani D, etal. Ethnicity, household composition and COVID-19 mortality: a national linked data study. J R Soc Med 2021;114:182-211. doi: 10.1177/0141076821999973. http://eprints.gla.ac.uk/237988/1/237988.pdf. pmid: 33759630

4 Office for National Statistics. Deaths involving covid-19 by vaccination status, England: deaths occurring between 1 January and 31 December 2021. 2022. https://www.ons.gov.uk/peoplepopulationandcommunity/birthsdeathsandmarriages/deaths/bulletins/deathsinvolvingcovid19byvaccinationstatusengland/deathsoccurringbetween1januaryand31december2021

5 Office for National Statistics. Coronavirus and vaccination rates in people aged 18 years and over by socio-demographic characteristic and occupation, England: 8 December 2020 to 31 December 2021. 2022. https://www.ons.gov.uk/peoplepopulationandcommunity/healthandsocialcare/healthinequalities/bulletins/coronavirusandvaccinationratesinpeopleaged18yearsandoverbysociodemographiccharacteristicandoccupationengland/8december2020to31december2021

6 UK Health Security Agency. Latest data reinforces the safety of COVID-19 vaccinations in pregnant women. Press release, 27 Jan 2022. https://www.gov.uk/government/news/latest-data-reinforcesthe-safety-of-covid-19-vaccinations-in-pregnant-women

7 Knight M, Bunch K, Cairns A, et al; MBBRACE-UK. Saving lives, improving mothers' care rapid report 2021: learning from SARS-CoV-2-related and associated maternal deaths in the UK June 2020-March 2021. 2021. https://www.npeu.ox.ac.uk/assets/downloads/mbrrace-uk/reports/MBRRACE-UK_Maternal_Report_June_2021___FINAL_V10.pdf

8 Knight M, Bunch K, Tuffnell D, et al. Saving lives, improving mothers' care lessons learned to inform maternity care from the UK and Ireland confidential enquiries into maternal deaths and morbidity 2017-1. 2021. https://www.npeu.ox.ac.uk/assets/downloads/mbrrace-uk/reports/maternal-report-2021/MBRRACE-UK_Maternal_Report_2021_-_FINAL_-_WEB_VERSION.pdf

9 OECD. Health at a glance 2021: OECD indicators. OECD, 2021, doi: 10.1787/ae3016b9-

10 GOV.UK. Ethnicity facts and figure: people living in deprived neighbourhoods. 2020. https://www.ethnicity-facts-figures.service.gov.uk/uk-population-by-ethnicity/demographics/people-living-in-deprived-neighbourhoods/latest

11 Office for National Statistics. Leaving no one behind-a review of who has been most affected by the coronavirus pandemic in the UK: December 2021. 2021. https://www.ons.gov.uk/economy/environmentalaccounts/articles/leavingnoonebehindareviewofwhohasbeenmostaffectedbythecoronaviruspandemicintheuk/december2021

12 Office for National Statistics. Mortality from leading causes of death by ethnic group, England and Wales: 2012 to 2019. 2021. https://www.ons.gov.uk/peoplepopulationandcommunity/birthsdeathsandmarriages/deaths/articles/mortalityfromleadingcausesofdeathbyethnicgroupenglandandwales/2012to2019

This article is made freely available for personal use in accordance with BMJ's website terms and conditions for the duration of the covid-19 pandemic or until otherwise determined by BMJ. You may download and print the article for any lawful, non-commercial purpose (including text and data mining) provided that all copyright notices and trade marks are retained. 